\title{
Central Banks and the Rights and Freedom of the Citizen
}

\section{O Banco Central e os Direitos e as Liberdades do Cidadão}

\author{
El Banco Central y los Derechos a las Libertades del Ciudadano \\ Henrique Schneider - Swiss Federation of Small and Medium Enterprises - $\underline{\text { hschneider@gmx.ch }}$
}

\section{Palavras-chave:}

Banco Central; Direitos;

Liberdade; Política

Monetária não

Convencional, Proibição do Dinheiro.

\section{Keywords:}

Central Bank; Rights;

Freedom; Unorthodox Monetary Policy; Ban on Cash.

\section{Palabras clave: \\ Banco Central, Derecho, \\ Libertad, Política \\ Monetaria no \\ Convencional, \\ Prohibición del Dinero.}

Recebido em: 06-jan-2018

Aprovado em: 18-fev-2018

\begin{abstract}
RESUMO
Quando os bancos centrais atuam, suas políticas e instrumentos não afetam apenas a economia, mas também os direitos das pessoas. Por esta razão, os bancos centrais dependem da política, uma vez que esta política é uma organização de decisões - em que os bancos centrais e os direitos das pessoas estão ambos incorporados. O mesmo se aplica a um nível operacional: os bancos centrais estão interligados com outras instituições, como por exemplo, com o Poder Executivo, agentes econômicos e a economia em geral através do dinheiro, das taxas de juros e, mais recentemente, da "política monetária não convencional". Este artigo examina como os bancos centrais operam buscando o alargamento do alcance de suas atividades, a expansão de seus meios e de seu tamanho. Será discutido que, assim fazendo, os bancos centrais reduzem as liberdades e os direitos dos cidadãos. Essa análise é então aplicada em dois casos, o da política monetária não convencional e o da proibição do dinheiro. Finalmente, serão discutidos meios de remediar a expansão das atividades dos bancos centrais.
\end{abstract}

\section{ABSTRACT}

When central banks act, their policies and instruments impact not only on the economy, but on people's rights as well. For this reason, central banks depend on politics, since politics is the organization of the polity - in which central banks and people's rights are all incorporated. The same applies to an operational level: the central banks are interconnected with other institutions, for instance, the Executive Branch, economic agents and the whole economy through money, interest rates, and more recently, through "unorthodox monetary policy". This paper examines how central banks operate pursuing the enlargement of the scope of their activities, the expansion of their means, and their reach. The aim of this article is to highlight that, by putting into practice what has been mentioned above, central banks reduce citizens' freedom and rights. This analysis is applied to two cases, the "unorthodox monetary policy" and the ban on cash. Given these points, the possible remedies of the expansion of the activities of the central banks will be discussed.

\section{RESUMEN}

Cuando los bancos centrales actúan, sus políticas e instrumentos no afectan solamente la economía, pero también los derechos de las personas. Por esta razón, los bancos centrales no pueden ser independientes de la política, una vez que la política es la organización de la política - en la cual los bancos centrales y los derechos de las personas están ambos incorporados. Tal hecho se aplica a un nivel operacional: los bancos centrales están interconectados con otras instituciones, por ejemplo con el poder ejecutivo, agentes económicos y la economía en general a través del dinero, de las tasas de interés y, más recientemente, de la "política monetaria no convencional". Este artículo examina como los bancos centrales operan buscando el ensanchamiento del alcance de sus actividades y la expansión de sus medios y su tamaño. Será discutido que, en así haciendo, los bancos centrales reducen las libertades y los derechos de los ciudadanos. Ese análisis es entonces hecho de manera plausible en dos casos, la política monetaria no convencional y la prohibición del dinero, Finalmente, serán discutidos medios de remediar la expansión de las actividades de los bancos centrales. 


\section{INTRODUCTION}

Intuitively, it is often assumed that freedom and rights belong together. Because people have freedom, they also have rights; because the individual has a certain freedom - for instance, the freedom of speech -, there is a proportional right - for example, the right to express (all) thoughts in public. However, from a perspective founded in classical-liberalism, it is much more logical to conceive freedom and rights as conflicting principles. Elements of this conflict are while freedom is active - it addresses the individual's potential, the rights of the citizen are nothing, but the concretization of a defense principle - the principle that the citizen can ward off interventions by the polity (GRAYLING, 2014).

There are other points of conflict, at least in the theoretical conceptions of freedom and rights. While freedom is by necessity for everyone, rights are primarily for citizens. They can be expanded, but at least some rights will remain the privilege of citizens, for example, voting or being elected to public office. Also, freedom is valid per se; rights are created by the polity, say through constitutional convention - sometimes, some rights are even granted to (some) people by a government ${ }^{1}$.

These and other conflicts become even clearer when rights of individuals vis-à-vis the polity become entitlements and they are interpreted to task the polity with facilitating access to the right in question. This happens, for example, when the right of free speech becomes the individual's entitlement to free schooling (in order to acquire the prerequisites for thinking freely). Another example is, when the right, of not being harmed, mutates into the entitlement of making other individuals refrain from expressing their views (since a view that someone disagrees, can be easily portrayed as harmful action). In short, there is an arc of tension between freedom and rights and on the supposed continuum from freedom over rights to entitlements as political categories. This paper analyses some of the potential conflicts on this arc; it does so, however, by examining the problem of freedom, rights, and entitlements in the context of central-bank-actions and their justifications.

Admittedly, this is an unorthodox approach to a discussion of the activities of central banks. However, it is the necessary frame if, as here, central banks are regarded as political agents. In particular, it will be shown that central banks are not agents independent from politics and which they, therefore, use political arguments, for instance, rights and entitlements, in order to advance their own agenda.

\footnotetext{
${ }^{1}$ For a practical examination of these conflicts, refer to: Becker (1980); the theoretical classic on how to reconcile these conflicts is in: Hayek (1973).
} 
Why are central banks political agents dependent on the political system in which they operate? First, they depend on politics because their actions relate to the public, especially to what they argue to be the rights of citizens. That is the very definition of politics. Second, their actions presuppose a connection between them and the other agents in an economy. Exactly because central banks are interwoven in a network of agents and transmission mechanisms, they are not independent (neither in an absolute, nor in a relative sense, as it will be discussed later). Third, and because of this embedding in a network, central banks cannot decide it independently: for their action to be "successful", they must relate their action to other agents and transmission mechanisms.

Not only that, central banks must anticipate how their actions might affect the other agents and transmission mechanisms before deciding what course of action to take. Central banks also underlie (somewhat) rational expectations. If, therefore, the independence of the central bank is the issue, the most that can be meant is: there is no direct influence of central banks by governments, by other political agents or by third-parties - however, not even this is given empirically; neither in Europe nor in the USA (O'DRISCOLL, 2013). In short: independency cannot mean that central banks are independent from the entire res publica - Latin for public thing, public affair, and opposite of the private sphere - that is politics, and because central banks act, their actions have an impact on the rights and freedom of citizens.

What does this paper set out to do? It examines how central banks - as political agents - use the rights of citizens (opposed to freedom) in order to advance their own agenda. First, this paper analyses the institutional settings in which central banks operate by examining the idea of freedom versus rights and entitlements. Then, the behaviors of central banks are discussed in terms of incentives and constraints given the institutional context. From these two aspects follows the mechanism of intervention to which central banks often resort. This mechanism will be shown using the examples of "unorthodox monetary policy" and the intended or looming interdiction of cash-money. Lastly, some proposals will be made on how to preserve the freedom of people in the face of the expansion of the activities of the central banks.

On a side-note, this paper will be using the following linguistic conventions. Maintaining neutrality with regard to state, government and the like, the paper will refer to all these mechanism as polity or institutions of the polity. Also, this paper will use the terms individuals, citizens and people synonymously. Finally, freedom and liberty will also be used synonymously. There is, however, a meaningful philosophical discussion about their different meanings. For example, in On Liberty, Mill differentiates between liberty as the freedom to act and liberty as the absence of coercion. Berlin notes two opposite concepts of liberty: positive liberty - a condition in which an 
individual is protected from tyranny and the arbitrary exercise of authority; and negative liberty liberty that comes from self-mastery, the freedom from inner compulsions such as weakness and fear (KELLEY, 1984).

All these conventions occur for simplification's sake. They allow this paper to focus on the central banks and the rights and freedoms of citizens. In the footnotes, there is additional material for those who want to explore the surveys and simplifications that this paper refers to and undertakes.

\section{RIGHTS VERSUS FREEDOM}

Interpreting freedom and rights as opposites requires a conceptual differentiation between two frameworks. One being the individual in relationship to other individuals and the other being the individual as citizen or member of a polity in relationship to that polity and its government (or structures of governance). Usually, these conceptual discussions employ an abstraction called "state of nature". It explores the hypothetical conditions of what the lives of people might have been like before societies and polities came into existence. As Skinner (1978) examines, as different philosophers as Mozi, Hobbes, Locke, or Nozick have employed these abstractions.

However, there is also another way of arguing both; a way grounded in the empirical development of human societies. Taking history as a point of departure, different episodes of the creation of a polity could be compared. In most processes of creation of polities, the idea of recording or giving rights to its citizens plays an important role. The comparison could aim at establishing reasons why to give rights to citizens and which functions the rights fulfill. Such a comparison is a far-ranging program for research in history and is out of scope of this paper. However, three episodes illustrate how the creation of polities is paralleled by giving or recording rights of the citizens, or, in a more normative interpretation, by subjugating citizens to the polity via the recording of their rights:

- Around the year 200 BC, China was molded for the first time into state-like Empire under the Emperor Qin Shi Huang. The Legalist School established itself as philosophical leader in the newly formed Empire. Thinkers such as Hanfei and Shang Yang envisaging a strong ruler in a strong state favored a model of statecraft based on law. According to them, the polity should mechanically apply these laws, reward those who obey and punish those who deviate from it. The system of laws, rewards and punishments was able to, for the first time in the history of China, give rights to the members of the polity. The Legalists' intention was simple: granting rights to 
citizens means subordinating them to the strong polity and making their actions - in the most purist view of Legalism: all actions - controllable by the polity (SCHNEIDER, 2011; 2018).

- In the so-called Athenian democracy (developing from the $5^{\text {th }}$ century Before Common Era), rights and obligations entailed equal contents. The right to participate in political assemblies was also a duty. No citizen that had a right of citizenship could rescind his - and they were all males - public duty. A withdrawal of the citizen to the matters of his private household would turn him in a self-referencing person - idiotes - and indicate his exclusion from all rights of the Polis. But, even if he participated, it would not be about the formation and discussion of political will. It would be about finding the one and right course of action. This course of action did not depend on the citizens, but on the pre-determined order of nature. The Logos - overarching reason that discovers the pre-determined order - dictated which course of action was good and bad, and it was the duty and right of the polity - Demos - and each of its citizens to implement that what they could recognize from the Logos. The Polis was committed to the Logos. In addition, the citizen was committed to the Polis. Being a citizen entailed having rights, but rights were not to be separated from the obligation towards the collective, or, to the Polis (SIEDENTOP, 2014).

On the occasion of writing and ratifying the US constitution around 1787, a controversy between the "Founding Fathers" James Madison and George Mason broke out. The Constitution did not contain a Bill of Rights. Madison thought it did not need one, since logic dictates that the people give themselves a constitution because they are natural holders of all rights. The polity should only acquire those rights which are explicitly given to it by the people, via the constitution. Therefore, whatever right has not been delegated to the polity, remains with the people. Mason, however, claimed the Bill of Rights to be absolutely necessary. He saw the newly created polity, not just as an institution dependent on the people, but as an active agent with an own agenda. This active agent called federal state would actively try to gain more power from and over the people. As a defense against an ever-expanding state-body, Mason wanted a Bill of Rights (CHENEY, 2014).

This brief and purely illustrative survey - which of course needs to be expanded shows how the idea of the citizens' rights was intended and used in different creations of polities. Common to them is that the polity uses rights to encroach upon its citizen. In two of the reviewed episodes, the citizens' rights go hand in hand with the citizens' obligation towards the polity - they even entail that the polity is above the citizens. In the third example, there is the controversy between the philosophical argument of the individual human being the holder of all natural rights and the institutional argument that wherever a polity is - and any artificial body, as principal-agentproblems tell (GROSSMANN; HART, 1983) -, it will develop an agenda that (also) increases its 
own power. Combining both positions, classical political liberalism, developed the doctrine of rights as the defense of the citizen against the polity. While this view seems to be implicit as early as in John Locke and explicit in George Mason's campaign against the Constitution and in favor of a Bill of Rights it was specially developed in the German-speaking context. ${ }^{2}$

This doctrine begins with the "social contract". When creating a polity, individuals renounce to (some of) their freedoms. They chose not to pursue all of their wishes and to delegate some tasks to the polity. For example, a certain individual might prefer to grow coca plant, sell, and consume Benzoylmethylecgonine (cocaine). If the person were completely free, it would be a matter of personal choice to do so. In a polity however, there are two possibilities. Either the polity has a rule by which it might regulate or interdict growing, producing, and exchanging the substance in question or it does have not. If it has no such norm, the individual citizen is free do to as it pleases. If the polity, however, has such a norm, it has the norm because the citizens of the polity decided to abdicate some of their freedom bestowing upon the polity the privilege of regulating some substances. In this case, the citizen shall - in the sense of a logical shall - abide by the rule. But, the important point of this argument is yet to come.

In order to compensate for this abdication of liberty, the same "social contract" offers remedies. These are directed against indiscriminate action by the polity and against the unmitigated expansion of the polity's regulatory and interventionist privileges. These remedies are the individual rights. This is the foundation of the so-called "status negativus": The polity has only those regulatory privileges explicitly bestowed upon it by the constitution, the "social contract" between its citizens and them and the polity itself. In addition, citizens can use their rights according to the constitution to ward off any interference of the polity that is not explicitly named in the constitution. The idea of the status negativus is that citizens can use their rights - the compensation for their abdication of freedom - against the activities of the polity and the polity has to abide by it. In the example above: it might be that the polity regulates the exchange of some substances, but it does not follow that the polity can regulate the polity can regulate all exchanges in all substances. If there is no regulatory privilege concerning sugar, the citizen can produce and exchange as much sugar as it pleases. If the polity attempts at constraining it, the citizen can use individual rights to ward off the polity's intended action.

It is also part of this doctrine that wherever there is a "social contract" - for example in form of a constitution -, there is not only status negativus but also "status activus". The latter denotes the citizens' rights of participation in the state. This participation is constructed as the formation of the political view, with reserved rights to disagreement.

\footnotetext{
${ }^{2}$ The following references provide an explanation of this doctrine: Cristi (1984); Brugger (1996); Gozzi (2007).
} 
While some versions of libertarianism might object to doctrine outlined above (ROTHBARD, 1998), it is, in a nutshell, the classical liberal way of addressing the threefold challenge of polity-creation, natural rights of individuals, institutional intentions of the polity and its officers. If people congregate (of free-will) and form a polity, it is clear that they abdicate - some or all of - their liberty and therefore need some instrument to ward-off polity-intervention. These instruments are individual rights, known as "status negativus". Since these people want themselves to manage the polity they created, they need procedural rights of how to participate in the public-body. Where the problems arise - form the classical liberal perspective - is, when the citizen's rights are interpreted as tasks for polity-action, or when rights are understood as entitlements.

Re-interpreting rights as entitlements and seeing them as reasons for polity-action, even immediate tasks for the polity, is called "status positivus". This interpretation became orthodox in the 1960s in the US and most European countries. The status positivus fundamentally changes the classical-liberal doctrine and inverts its direction of thought. Instead of understanding individual rights as a remedy against actions undertaken by the polity, this new interpretation of individual rights sees in them a mandate for the government to become ever more active (POSCHER, 2003). In addition to the inversion of logic, there are further problems with this understanding of individual rights as a mandate to the polity. Positive rights require the Executive Branch of the polity to take action; also, they are often criticized because they give rise to the justiciability problem. Executive bodies and courts, rather than democratic legislatures, decide upon the scope and content of the rights. And even if the positive aspect of a right is pursued by the legislative, it usually is at the expense of other individual rights; i.e. not only curtailing the rights of other citizens, but also diminishing the protective power individual rights were meant to have in the first place (SUNSTEIN, 1993; CROSS, 2000).

An actual example shows the inversion do logic as well as the problem of arbitrariness. Without a polity, each person could think, say, and propagate ideas constrained only by the individual's dexterity in doing so. In a polity, to ward off possible encroachment by the polity, there usually is a right to free speech. Status negativus stipulates that the polity cannot forbid individuals to express their thoughts in public. If it attempts at doing so, citizens use their rights against the intervention by the polity and continue to express their views freely.

However, what does status positivus postulate? It could entail different tasks for the polity, each to be instituted by an executive, and if contested, by a juridical act. The right to free speech can be interpreted with status positivus as entitlements and, therefore as the duty of the polity to provide for free schooling. After all, only educated citizens are able to express their 
thoughts. It can also mean that the polity has to provide for a neutral internet and search therein. After all, freely expressed thoughts should also freely reach an audience. But the same right of free speech in its status positivus interpretation could mandate the polity to curtail certain expressions of views if they are thought as harmful or perilous. After all, harmful views impact negatively on other people's opinions making it more difficult for the harmed people to develop and express their views freely. In a status positivus view, rights can be used for broadening the scope of polity-action, and even against the citizen. In short, status positivus gives the polity the privilege of the interpretation of individual rights. They are discontinued as the citizens' remedy against their abdication of liberty and re-invented as the polity's mandate to interpret and act on its own discretion - even against the citizen.

Switzerland is one of the few countries founded on the philosophical doctrines of classical liberalism. Its first constitution of 1848 only passed because of its explicit commitment to the status negativus and status activus. However, in the 1990s, the status positivus became accepted by courts and in the new constitution of the year 2000, it even became a constitutional principle. More than the anecdotal evidence, this example is important because of the clarity of the argument in committing the new "social contract" to the status positivus. The explanatory materials of the new constitution - a booklet issued with the constitution containing its interpretation as the institutions of the Swiss polity understands it - says about Article 353:

Paragraph 1 expresses that fundamental rights are the foundation of our legal order and that they should be applied in the totality of our political system. It gives public authorities a general mission to ensure the effective implementation of fundamental rights, i.e. to employ all appropriate means to achieve the desired objective. This contract includes first making a commitment to refrain from any activities that could harm the fundamental rights; this corresponds to the classical function of fundamental rights as rights of defense, which impose on the State a duty of discretion. The contract, however, contains further the obligation of public authorities to act so that fundamental rights are protected and promoted (positive function).

And the Swiss Supreme Court ${ }^{4}$ noted in 2000 (Baselbieter Banntag):

\footnotetext{
${ }^{3}$ Swiss Confederation. Art. 35, I.192. BBI, 1997.
}

${ }^{4}$ Swiss Supreme Court. BGE 126 II. 2000, p.314. 
According to the new constitution, fundamental rights not only have a defensive function against interference by the state, but also establish a State duty to protect against threats that are caused by third parties. This concept was developed mainly in Germany (...). It is also represented in the Swiss doctrine and jurisprudence (...). Also, Article 2 of the European Charter of Human Rights ECHR requires State Parties to protect life positively (...). The European Court of Human Rights has then derived from the freedom of private and family life (Article $8 \mathrm{ECHR}$ ) a state obligation to protect threatened fundamental rights (...).

The Swiss example shows the dramaturgy of the classical liberal doctrine of the status negativus. For a long time, it served as the sole or dominating principle of polity-action in the Swiss Confederation. But, it quickly turned into its exact opposite: the executive re-interprets the individual rights as entitlements and as mandates to act or as tasks. The Judiciary seconds the interpretation. Together, it is at their discretion to define how to operationalize the mandate. But, the Swiss example also shows the self-fulfilling character of status positivus. If the polity is free to stipulate new individual rights to its citizens, it is incentivized in doing that. The reason is: under status positivus, granting more individual rights automatically leads to new mandates and tasks, thus to a larger polity with an expanding scope of activities and an expanding range of privileges.

Summing up: From the classical liberal perspective, individuals give up (some or all of their) freedom when they socialize in a polity. In order to prevent the polity from restricting the remaining freedom, individual rights are made part of the "social contract" of the constitution in order to defend the citizens against the activities of the polity. Individual rights are the citizens' remedy against their abdication of liberty. Citizens can use their individual rights to ward off activities by the polity - so far does the status negativus go. On the other hand, status positivus reinterprets individual rights as entitlements and as mandates for polity-action. Status positivus creates discretion for the polity, since it is the public body that tasks itself with identifying the tasks mandated by the rights. It also incentivizes this body to grant ever more rights to the citizens, because the more it grants, the more it expands its mandate. At the end, individual rights can be used by the polity to either encroach even more on the citizens' liberty, or to suppress it completely.

This is the explanatory model developed in this paper. It will be applied to the actions of central banks worldwide, not without specifying how central banks are political agents. They are instantiations of those bodies of the polity looking for the expansion of their activities, or, following an agenda of their own. 


\section{CENTRAL BANKS AND POLITICS}

Before applying the explanatory model developed in the former section, this section takes a closer look at central banks as agents of the polity, i.e. as political agents. Conceptualizing how central banks behave is important for analyzing how they act politically and how they understand or use the rights of the citizens under status positivus. One of the most important aspects of the behavior of central banks is their consistent claim to be independent.

However, what does independence mean, exactly? From whom or from what are central banks supposed to be independent from? While the focus of analysis of the last section was an institutional setting - the rights of the individual - this section focusses on the structure of incentives and constraints under which central bank operate. Central banks claim their behavior to be independent. This section asks what independence is and, given the institutional framework discussed in section one, to what type of actions the incentives and constraints of independence could most likely lead.

Before discussing its meaning, a brief survey of how independence became one of the most important aspects of the behavior of central banks might ease the understanding of the contingency it entails. As it did in the previous section, the caveat also applies here: this is an illustrative survey - it is a research program of magnitude in itself; one that does to fit the scope of this paper:

- In the United Kingdom, the Treasury Department set the base interest rate up until 1997. The Bank of England's call for independence was an attempt to broaden its own responsibilities from monetary policy to the determination the base rate (JOYCE; LILDHOLDT; SORENSEN, 2010).

- In Europe - and also in the United States and Canada - the demand for an independent central bank was justified politically and through state-consequentialist arguments. The claim was that the independence from party-led influence leads to lower inflation, which would benefit the economy as well and the people, and make the polity stronger (CUKIERMAN, 2008).

- In the United States, where the central bank has a dual mandate - price stability and full employment - independence means only that it determines its own budget; the US Federal Reserve Act 2013 is explicit about the central bank being "independent within the government".

- More recently, some central bank officers have questioned the need for independence. This thinking is based on state-consequentialism as well. According to their argument, the demand for independence is superfluous in a world of low inflation. On the contrary, 
concerted cooperation with the elected representatives is necessary to ensure the stability of the financial sector and to maintain the polity's control over the economy (FISCHER, 2015).

This purely indicative survey indicates, first that the concept of central bank independence is contingent on the economic environment; and second that the concept itself is often argued on a state-consequentialist logic. This logic can be roughly described along these lines: "what makes the polity stronger should be pursued." In the arguments recollected above, there is a second form of consequentialism, which is institutional-consequentialism. This logic can be roughly described, as "what makes the institution (i.e. central bank) stronger should be pursued. This analysis, however, it not sufficient for gaining a deeper understanding of what independence is; and so this line on enquiry continues.

From whom or what are central banks supposed to be independent? It might help to assert, first, what independence cannot mean. Central banks can hardly claim to be independent from the public sphere as a whole because they operate within the public sphere. In fact, being in the public sphere is a precondition to being a central bank. In addition, it is unlikely that independence means such from the financial sector since central banks need the financial sector as transmission mechanisms of their policies. Furthermore, central banks currently oversee and in some polities regulate financial sectors, which require a link between both. This link is not there by necessity, but by systemic design. Lastly, central banks cannot be independent from the structures of governance of the polity, more precisely, of government. After all, central banks are subject to the law of their respective polities and they are mandated by them.

However, the most important reason for central banks not being independent from the government of polities is the following: central banks want to influence (or determine) the actions of agents in the polity. This objective, by itself, presupposes a link between the central bank, the polity and the economic agent. But, in order for this objective to be operationalized, central banks are keen on using the regulatory privilege of the polity in order to impose and diffuse their policies. Central banks using the regulatory privilege of the polity make them part of the institutions of the polity, in turn, turning them dependent on these institutions of governance.

Therefore, central banks are public agents, interlinked with some sectors of the economy, at least the financial sector, and embedded in the structure of governance of the polity, in its government. While the first form of dependency exists by necessity, the other two occur by the design of the institutional framework in which central banks operate. The idea of central bank independence requires therefore some nuance.

There is a "classical" definition of what central bank independence could mean. Walsh (2010, p. 21-26) says: "Central bank independence refers to the freedom of monetary 
policymakers from direct political or governmental influence in the conduct of policy." Nevertheless, even this case is less straightforward than it seems to be. This definition only rules out the direct influence. Behavior, however, is also about indirect influence, rational expectations, revealing and concealing of information, among other things.

The so-called independence in decision-making by central banks can, at most, extend to some, but not all aspects of their behavior. Decisions presuppose epistemic states. Examples of such states are knowledge, models about how other agents might behave or respond to one's own actions, ways of gaining information, interpreting it and signaling its interpretation to other agents. These examples - and they only address a small subset of epistemic states - already show how dependent central banks are. For gaining knowledge, central banks need a vast number of sources, make them market processes, dealers of information like journalists, academics and think tanks, or even other institutions of the polity. The models on which central banks rely are developed by academia or the financial sector, that is, by the same the agents the central bank wishes to influence. For transforming information into knowledge and for diffusing information as well as knowledge, central banks need different intermediaries, for example own structures of communications, journalists, or the financial sector. But, most importantly, in order for their policies to be diffused, central banks need the regulatory privilege. Besides, in order to develop these policies, central banks anticipate how other agents, especially other institutions of the polity, will respond to them. There is one way for central banks getting more information about these responses: directly communicating with these other institutions. So, it may be that central banks are not directly influenced by other institutions of the polity (or by the institutions of the financial sector), but by merely communicating with them in developing policies, central banks are dependent on the information given to them by these institutions. There is an epistemic and practical dependence. At the end, there remains only a very limited scope for true independence of central banks (MCCALLUM, 1997; 1995).

There is a much more convincing interpretation of central bank independence: it could be a political demand voiced by central banks in order to enlarge their scope of action. In consequence, central bank independence becomes a normative demand pursued by an institution of the polity and ceases being a factual feature of the central banking system. As clever political rhetoric, the demand for independence simply prevents different forms of dependence which would constraint the institutional scope of central banks - for example, control by other institutions of the polity. If a central bank demands to be independent, it means that it does not want to be bound, for example by congressional oversight, by rules (exogenous to them) in monetary-policy, or by procedural rules in gaining and dispersing information and knowledge inter alia. Central bank 
independence seems, at a first sight, a technical, institutional feature, but is revealed to be a political demand based on the behavior of an agent that seeks to expand its possibilities of action.

In the cases mentioned above, the justification for the so-called independence of the central bank is always state - or institutional-consequentialist. That is, independence is not a value in itself, but a means to a specific purpose - determination of interest rates, inflation control, ensuring the stability of the financial sector or stimulus to economic growth. And, since independence is merely a means, it should not come as a surprise that when objectives change, new means are sought. For this reason, it is impossible to describe precisely what independence is. Its specific content is always dependent on the goal of central banks; if the goal changes, the meaning of independence changes. It changes so much that even its own elimination is possible. If the aim is, as Fischer (see above) proposes, to ensure the stability of the financial sector, the enhanced co-operation between the central bank and the other institutions of the polity can become the preferred means.

Looking at the incentives and constraints of central bank behavior in this setup might further elucidate this conclusion. Under status negativus central banks would only be in charge of the tasks bestowed upon them by the "social contract". Under status positivus, however, they are free to interpret their mandates not in a narrow, but in a wide sense. Wherever a situation permits an analogy to their mandates, they automatically derive legitimization to act. This mechanism incentivizes central banks to be on an active lookout for reasons to expand their mandates, the regulatory privileges they have and the size of their institutions. They did and do so, for example, when they decide that not only monetary stability, but the stability of the financial sector is to be addressed by them; or they act based on these incentives when they decide that theirs is the job not only to help remediate financial crises but to make any future economic turmoil impossible.

This behavior faces constraints, namely the regulatory and institutional embeddedness of central banks. So, central banks attempt at shaping these constraints in their favor. Once by declaring independence - or, the possibility of institutional arbitrage - as a precondition for their actions and once by declaring cooperation with other regulatory bodies to be useful. Tacitly, central banks shift to the former when they expect to take a leadership role in the governance of cooperation, which leads to, once again, the expansion of their scope of operation, their means, and their size. However, central banks need to make their case not only based on what they wish, but on what compels the polity to empower them. Here, the status positivus serves in a twofold way. First, it provides a vector for the consequentialist argument because it follows itself consequentialist logic; and second it allows the amalgamation of three desiderata - the intended consequences of action undertaken by the polity and its agents -, the empowerment of the central 
bank, the strengthening of the polity, and the advancement of the rights of citizens, as conceived by status positivus. How this happens will be discussed in the next section.

\section{CENTRAL BANK AND RIGHTS}

The first section of this paper addressed the institutional framework under which central banks - inter alia - operate in most contemporary polities. The second section showed how central banks behave within this institutional framework. The present section exemplifies this analytical framework developed by the previous sections using two cases of central banks expanding their scope of activities in function of the rights of the citizens, as constructed by the status positivus. For recapitulation's sake, let the mechanism discussed in the previous sections be stated as the following:

Under status positivus, the rights of the citizens (and other individuals) are interpreted by (usually the executive and judiciary branches of) the polity as entitlements. Interpreting rights and entitlements leads to an expansion of the mandate for the polity and its institutions. This is self-referential because it is the polity itself that interprets rights as entitlements; and it is the polity itself that states how its mandate is enlarged by the entitlements. Consequentially, under status positivus, the polity is on the constant outlook for new rights, entitlements, and mandates. Central banks as institutions within the polity use the same mechanism under status positivus to expand their scope of activities, means, and size. The constant expansion of the polity's actions leads to a decrease in individual rights as they are understood under status negativus, and therefore, to a decrease of freedom. The application of the mechanism as well as its consequence for freedom will now be explain along the cases of "unorthodox monetary policy" and "ban on cash".

\subsection{Unorthodox monetary policy}

"Unorthodox monetary policy" is probably to be understood as a collective term for a variety of related measures. They all serve three objectives: Increasing the stability of the financial sector, stimulating economic growth, and achieving full employment (RAJAN, 2013). Note that there are no "orthodox" goals under the three objectives. Examples of "orthodox goals" are providing remedies against monetary imbalances (inflation and deflation) or ensuring a stable framework for the circulation and exchange of currency. Instead, the above objectives belong either to what are typically regulatory privileges of the polity (first objective); or to fiscal policy, i.e. to the influencing the economic cycle through polity-driven expenditures and/or investments (the 
second and third objectives). "Unorthodox monetary policy" is, therefore, the expansion of central banks' activities into new realms. Note how the three new realms for central banking used to belong to the legislative branch of the polity; under "unorthodox monetary policy" they are tacitly transferred to an executive agency. With a grain of salt: an institution of the polity is empowering itself at the expense of that institution that is nearest to the control by the polity's citizens.

At the level of the instruments, the most important ones in the "unorthodox monetary policy" are the invention of macro-prudential supervision - this usually entails capital buffer regimes directed by the central bank on the individual banks' level, regulation of loans. Especially those secured by real estate, measures to limit systemic risk of individual banks, and the reciprocal use of macro prudential measures by different polities -; the introduction of negative interest rates - interest rates in which credits are debited -; quantitative easing and other balance sheet measures - these consist in the direct purchase of securities by a central bank to redirect money in the financial markets immediately -; "forward guidance" - a form of communication in which the central bank influences the agents in the market processes by disclosing information about its future activities -; and in some cases asymmetrical measures in the exchange rate - for example, the Swiss central bank's policy of the fixed exchange rate lower limit Swiss Franc to the Euro in the years 2011 - 2015 (BORIO; DISYATAT, 2010).

The same re-interpretation of central banks' aims explained above is paralleled on this instrumental level. The first instrument mentioned here is of regulatory nature and belongs, as such, to the legislative realm. The other instruments, in particular "quantitative easing", "negative interest rates" and the measures related to the exchange rate bear the character of fiscal policy, i.e. the intention of influencing the economic cycle. Through the development of this new portfolio of instruments, central banks legislative and increased their executive roles. In doing so, they expanded the scope of their activities, increased their means, and size. But, it is not the fact, as such, that is interesting. The argument for doing so falls exactly under the characterization of the mechanism exposed here.

With the incidence of the financial crisis in the years 2007-2009, various polities tried to counter the crisis. Both the aims stipulated as well as the instruments employed broadly followed an argumentative logic based on the rights of citizens interpreted as entitlements from which mandates to the polity automatically derive. The argument went as such: the crises diminish the welfare of the citizens; but citizens have a right to welfare. Since the right of welfare is an entitlement of the citizen, it automatically follows that the polity has the task to intervene into the economic system; at least until the pre-crises level of welfare is restored. However, from the citizens' entitlement to welfare also automatically follows that the polity should take measures in 
order to make any further crises impossible (TEMPELMAN, 2010). Since central banks were firstmovers in the articulation of this argument as well as in the deployment of measures, they emerged as leaders of this type of cooperation between them, the other institutions of the polity, and the financial sector. They used their independence in order to become first movers and once they were well positioned, they started championing cooperation.

This logic only works if the polity accepts the status positivus. Under status negativus, a different understanding would emerge, namely and roughly that there is nothing that the polity could do and the crisis was rather a consequence of too lax monetary policy in in 2000s and overregulation of productive usages of money. There is an abundant literature on why the type of policy response deployed by central banks is at least problematic (TAYLOR, 2012; WHITE, 2012). This paper's task, however, is to assess how the freedoms of the citizens are impacted by such activities.

One important freedom is private property; and if translated into the language of constitutions, there is a right to private property and the inviolability of private property. The status negativus is quite: the polity cannot confiscate or otherwise violate, directly or indirectly, private property. Via status positivus, elements of the "unorthodox monetary policy" directly violate and even confiscate private property.

One example of this violation is the negative interest rates, which are effectively a confiscation of a private capital. Quantitative easing is another example because its mechanism relies on the externalization of its risks. If it fails, it will be the citizens who will suffer to consequences of this failure. But, there is an even more direct violation of private (capital) property by quantitative easing: the mechanism itself distorts short and long term investment parameters, favoring the latter over the former and inducing citizens not to accumulate capital, to become less productive, and - in conjunction with negative interest rates - consume more. This is even problematic by the point of view of welfare, since it is through capital accumulation and the increase of productivity that welfare rises. But also, forward guidance and macro prudential supervision are restrictions on the citizens' liberties. These instruments not only artificially raise or lower the value of certain - or all - investments, transactions, and entities, but they also interfere with the citizens' capability of scrutinizing market-processes for information.

\subsection{Banning cash money}

Banning cash is the polity-engineered migration of all payment flows of money and coins, as well as their surrogates, to electronic payment systems such as credit and debit cards, or 
direct electronic exchange. This topic comes up regularly. For example, a consortium of central bank representatives held a meeting about this issue in 2015. There are different explanations for the motivation of central banks for this proposal. In some cases it is the naive belief that terrorism could thereby be stopped - as if terrorism was expensive and terrorists travelled the world with suitcases full of money. In other cases, it is about fighting the unregulated sectors of the economy - as if no shadow currencies could be established. In still other cases, it comes to minimizing the cost of the money supply and increasing the safety of the people - as if there were no hackers and no other disturbances to electronic flows. ${ }^{5}$

Two types of motivations behind the proposal are of interest here - but the argument could be extended to practically all: the idea that without cash-money, individuals would consume more; and the aims of enhancing central banks' policies via a direct link between them and the citizens; i.e. without the "interruption" imposed by cash money.

To the first, the Keynesian-inspired economist Mankiw suggested in 2009: in an environment with negative base rates, central banks could announce an annual number of 0 to 9 in a lottery process. All banknotes with this number at the end of their registration number would then be invalid. Any agent, who is in possession of a lot of cash, would then have to fear losing a tenth of his assets in one year. Suddenly zero interest rates or even negative returns would become attractive. People would be delighted to lend money at minus three percent, since losing three percent is better than losing ten percent - for sources see Schneider $\left(2015^{a}\right)$.

Without the "real" - this is not the place to discuss what real money is. Let it be assumed, for the sake of simplicity, that cash is among the most real forms of money, especially in comparison to electronic payment systems - money in their hands, i.e. with abstract representations in form of balance sheets, credit cards, and debit cards, individuals would be more willing to spend more money. Simultaneously, savings become an inferior option. This incentive to consumption leads to economic growth and full employment. So far goes the Keynesian proposal.

But, for example Rogoff $\left(2016^{a}\right)$ and central banks take it one step further. The increased transparency in the payment system leads to more data about how individual's live. With this data, different aggregators of information could gain enough understanding necessary for a wide range of activities. Some could, for example, engage in targeted advertising, once again stimulating consumption, growth, and employment. Tax agencies could monitor individuals and firms closing potential gaps in the collection of taxes. But, most importantly, in a world without cash money, the "unorthodox" instruments described above would directly percolate to the

${ }^{5}$ For sources, see: Rogoff $\left(2016^{b}\right)$; Schneider (2015). 
individual sphere, i.e. central banks would carry less transaction costs. The idea behind this is that cash is a disruption in the transmission of central banks' policies to the individual citizens. With the elimination of this disruption, the transfer is immediate.

The same mechanism described above is at work here. At the time of writing, cash bans are not real. However, central banks and academics are increasing the pressure. All central banks and some academics are resorting to an argument based on the status positivus, and again, on welfare: citizens are entitled to welfare and it is the central banks' mandate to provide for this entitlement. Without cash money, it would be easier for fiscal and monetary policy to increase the welfare of citizens; without transaction costs of these two policies, financial and possibly real crisis can be made impossible and economic growth can be stimulated.

From a point of view grounded on the status negativus, however, banning cash-money is a blatant violation of the citizens' rights. According to status negativus, citizens should be able to use their rights to economic freedom to ward off such plans by central banks. An abolition of cash money makes it even easier for the polity to directly influence the lives of individuals and to determine (all of) their investment, savings, and consumption decisions, which amounts to a decrease in freedom. The violation of the rights of the citizens under status negativus by a possible ban on cash money is even more extensive than "unorthodox monetary policy". In addition to the expropriation or the distortion of investment decisions, the entire loss of financial privacy as well as the loss of control over one's finances is fundamental.

In both cases, institutions of the polity - principally, central banks, re-interpret welfarerelated rights of the citizens as entitlements to welfare and as mandates to themselves to act. Using the status positivus, these institutions replace individual freedoms by collective steering, even at the cost of the citizens. Ironically, without financial responsibility over one's own accounts, especially with respect to decisions about savings and consumption, the individual the citizen is depraved of one of the most important motivations for the increase of productivity and, thus, of individual welfare. Moreover, policies rewarding - possibly credit-based - consumption tend to lead to the social decline of the individual, diminishing, therefore, the citizens' welfare. This is because consumption is not linked to productivity and does not require a learning curve or innovations, which are the sources of social ascendance - for a more thorough discussion of this mechanism see Schneider $\left(2015^{b}\right)$.

To conclude: this section merged the institutional framework developed in the first with the analysis of central banks' behavior of the second applying them to explain two cases. In "unorthodox monetary policy" as well in the possible ban of cash money, central banks build an argument based on the status positivus re-interpreting rights of the citizens as entitlements, in this 
case the entitlement to welfare. Central banks further re-interpret these entitlements as mandates for action. In a first step and basing on their supposed independence, they bypass any form of political control and make use of non-scrutinized elements. In a second step, after having asserted themselves as leaders, they form a coalition with other institutes ensuring the continued application of their instruments. In both cases, it becomes clear that central banks use the status positivus to enlarge their scope of activities, their means, and their size. In both cases, it also becomes apparent that these actions are detrimental to the citizens and that the citizens' rights are violated.

\section{FREEDOM WITH AND WITHOUT CENTRAL BANK}

The previous three sections were analytical in as far as they asked a question as evaluated the answer by taking a look at an institutional setup, at the behavior of an important agent, and at "empirical" cases. The finding is that central banks infringe on the freedom and rights of citizens, especially in the contemporary context. This section, however, is of prescriptive nature. It goes back at classical liberalism asking what can be done to curb the expansionary drive of central banks and to safeguard the citizens' (vestigial) freedom. On the other hand, this section is not directly prescriptive because it serves as a reminder of work to be done. As there are different remedies grounded in classical liberalism, this section only sketches some of them out. They all deserve a much deeper discussion that can be accomplished by the remainder of this paper. Some of the remedies against expansionary central banks are:

- The abolition of central banks is a possibility. It would not mean abolishing cash or money, but merely eliminating the central institution as a "lender of last resort" and the provisions on some money serving as "legal tender". Individual banks or financial institutions would issue their own money and it would be a matter of the market, more precisely, of the different agents in the market to use and to accept this money. These agents would share the financial risk with the issuing institutions. A competition for currencies would be established. Note that this system works with or without fractional reserve banking.

- One way of accepting the currency monopoly of an institution and still avoid the misuse of its market power are parallel or surrogate currencies, which would be privately regulated. These would be used by individuals in parallel or in addition to the monopoly-currency. Parallel currencies are usually foreign currencies or real assets that graduate to currencies. This usually happens in times of (central bank-induced) emergency, such as inflation. Surrogate currencies are usually special payment means inspired by reserve currencies. But, there are 
surrogate currencies that are at least formally not attached to a reserve currency, for example, miles and points in the loyalty programs of airlines and hotels or cryptocurrencies like Bitcoin.

- There are possibilities of maintaining central-banks monopoly over the currency and still control their behavior. For example, monetary policy can be linked to an exogenous standard. Often gold is proposed as such a standard. In this system, the central bank has a monopoly, but it cannot exercise its entire monopolists' power, for monetary policy - and the instruments at the disposal of central banks - is determined by an exogenous entity that cannot be influenced, gold. But, this exogenous standard could also be a set of rules for monetary policies, for example mandating central banks to operate under the Taylor-rule. Thus, central banks can use fewer instruments in monetary policy. However, it is questionable whether exogenous standards would prevent the central bank from expanding its sphere of influence, particularly in the regulatory sector. Doubtless its economic policy intentions would be limited.

- Another way of restricting the monopolistic power of central banks is to force the competition of funds and currencies, for example, by permitting several currencies to be used simultaneously in a currency area as a means of payment and value retention.

- There is also the possibility of institutionally limiting central banks, for example by breaking them up into several institutions. One institution would be responsible for currency; another, at least functionally independent from the first, for the interest rate; a third of cash flows, etc. The coordination of these agents would become difficult for themselves and, ideally, a competition between them would establish itself.

- Instead of breaking up a central bank into different institutions, it is also possible to strip them of some tasks, the interest rate policy making putting the legislative branch in charge of it. Thus, real scope of action of central banks would be diminished and coordination with other political agents limited. This remedy could even foresee not an institutional separation of tasks, but the abolishment of tasks altogether, for example by letting the market processes set interest rates on their own.

- However, one of the most important levers to curtail the activities of central banks and of the polity in general - is the resumption and enforcement of the status negativus. Individual rights should be understood again as a remedy of the individual to ward off encroachments by the polity on the citizens' freedom. This could be accomplished by a variety of ways, for example by allowing any citizen to sue the institution that is encroaching on the citizen's freedom. Moreover, a reversal of the burden of proof could be instituted. Institutions of the polity would have to prove "beyond reasonable doubt" that their activities do not affect any of the citizens' rights. Alternatively, a "positive list" of actions by the polity could be established. If any of its items is extant, the actions 
of the polity would be automatically deemed as infringing on the citizens' rights. It is important to establish this process as a defensive one. I.e. no individual should receive compensation for warding off incursions of the polity; the status negativus establishes halts to activities of the polity.

Of course, these prescriptions against overbearing activities of the polity must undergo a much deeper assessment. The intention of this final section, however, was to show that classical-liberalism not only diagnoses the problems of contemporary polities, but also has antidotes to offer. Most of the remedies mentioned here address either the institutional setup of polities or the behavior of the institutions therein, in case, central banks. The last remedy, however, refers back to rights and freedoms. By returning to the status negativus, it attempts at preventing right to be reinterpreted as entitlements and it wants to stop the polity to reinterpret its tasks in function of supposed entitlements.

\section{REFERÊNCIAS}

BECKER, Lawrence. Property Rights: Philosophic Foundations. Routledge, London, 1980.

BORIO, Claudio; DISYATAT, Piti. Unconventional monetary policies: an appraisal. The Manchester School, v.78, n.1, 2010.

BRUGGER, Winfried. The image of the person in the human rights concept. Human Rights Quarterly, v.18, n. 3, 1996.

CHENEY, Lynne. James Madison: A life reconsidered. Penguin, New York, 2014.

CRISTI, Friedrich. Hayek and Schmitt on the Rule of Law. Canadian Journal of Political Science/Revue canadienne de science politique, v.17, n.3, 1984.

CROSS, Frank. The error of positive rights. Los Angeles law Review, University of California, v.48, 2000.

CUKIERMAN, Alex. Central bank independence and monetary policy making institutions —Past, present and future. European Journal of Political Economy, v.24, n.4, 2008.

FISCHER, Stanley. Central Bank Independence. Herbert Stein Memorial, Lecture National Economists Club, 2015. Disponível em: <http://www.federalreserve.gov/newsevents/speech/fischer20151104a.htm\#f5> Acesso em: 6 jan 2018. 
GOZZI, Gustavo. Rechtsstaat and individual rights in German constitutional history. In: COSTA, Pietro; ZOLO, Danilo (eds.). The Rule of Law History, Theory and Criticism. Dordrecht, 2007.

GRAYLING, Anthony. C. Towards the light: The story of the struggles for liberty and rights that made the modern West. Bloomsbury Publishing, London, 2014.

GROSSMANN, Sanford; HART, Oliver. An analysis of the principal-agent problem. Econometrica. Journal of the Econometric Society, v.13, n.1, 1983.

HAYEK, Friedrich A. Law, legislation and liberty. University of Chicago Press, Chicago, 1973.

JOYCE, Michael; LILDHOLDT, Peter; SORENSEN, Steffen. Extracting inflation expectations and inflation risk premia from the term structure: a joint model of the UK nominal and real yield curves. Journal of Banking \& Finance, v.34, n.2, 2010.

KELLEY, David. Life, liberty, and property. Social Philosophy and Policy, v.1, n.2, s/l, 1984.

MCCALLUM, Bennett. Crucial issues concerning central bank independence. Journal of Monetary Economics, v.39, n.1, 1997.

MCCALLUM, Bennett. Two fallacies concerning central bank independence. National Bureau of Economic Research, s/l, 1995.

O'DRISCOLL, Gerald. Debunking the myths about central banks. Wall Street Journal Online 15. September 2013. Disponível em: <http://onlinewsj. com/article/SB10001424127887323468604578252443925155434. html> Acesso em: 6 jan 2018

POSCHER, Richard. Fundamental rights as defensive rights: reflexive control legally ordered liberty. Mohr Siebeck, Tübingen, 2003.

RAJAN, Raghuram. A step in the dark: unconventional monetary policy after the crisis. Andrew Crockett Memorial Lecture, Bank for International Settlements, 2013.

$\underline{a} \underline{b}$ ROGOFF, Kenneth. The curse of cash. Princeton University Press, Princeton, 2016.

ROTHBARD, Murray. The ethics of liberty. New York University Press, New York, 1998. 
a $\underline{b}$ SCHNEIDER, Henrique. Bargeld verbot: Wirts chafts politische Utopie im Zeitalter unorthodoxer Geldpolitik. The Liberal Institute Working Paper Series, no. 1/2015.

SCHNEIDER, Henrique. Legalism: Chinese-style Constitutionalism? Journal of Chinese Philosophy, v.38, n.1, 2011.

SCHNEIDER, Henrique. The Way of the Ruler: Introducing Hanfei's Political Philosophy. Cambridge Scholar's Publishing, Cambridge, 2018.

SIEDENTOP, Larry. Inventing the Individual: The Origins of Western Liberalism. Harvard University Press, Cambridge, 2014.

SKINNER, Quentin. The Foundations of Modern Political Thought. Cambridge University Press, Cambridge, 1978.

SUNSTEIN, Cass. Against positive rights. Eastern European Constitutional Review, v.2, n.1, 1993.

TAYLOR, John. Monetary policy rules work and discretion doesn't: A tale of two eras. Journal of Money, Credit and Banking, v.44, n.6, 2012.

TEMPELMAN, Jerry. Austrian business cycle theory and the global financial crisis: Confessions of a mainstream economist. Quarterly Journal of Austrian Economics, v.13, n.1, 2010.

WALSH, Carl. Central bank independence. In: DURLAUF, Steven; BLUME, Lawrence (eds.). Monetary Economics. Palgrave Macmillan, London, 2010, p.21-26.

WHITE, William. Ultra-easy monetary policy and the law of unintended consequences. RealWorld Economics Review, v.1, n.1, 2012. 